\title{
Population responses of coastal zoobenthos to stress induced by drifting algal mats
}

\author{
Alf Norkko*, Erik Bonsdorfi \\ Husö Biological Station \& Department of Biology, Ảbo Akademi University, FIN-20520 Åbo, Finland
}

\begin{abstract}
In the large archipelago area of the northern Baltic Sea, increasing occurrences of drifting benthic macroalgae have been recorded in the subtidal zone. Their role as a structuring factor on the zoobenthic community has been altered from inducing occasional small-scale disturbances to inducing large-scale mortality of macrobenthic populations. A controlled field experiment was conducted on a sandy bottom in order to test for temporal responses of benthic invertebrate populations to severe stress imposed by the algal mats. Algae corresponding to amounts recorded in the field were enclosed in netbags and attached to the bottom. Population abundance of the zoobenthic species under algae were compared with control plots for $5 \mathrm{wk}$ with weekly sampling. Massive die-offs of benthic populations were recorded in both the experiment and under natural occurrences of drift algal mats. The community dominants in abundance (mudsnails Hydrobia spp.) and biomass (bivalve Macoma balthica) exhibited strong population reductions after $9 \mathrm{~d}$ of algal stress. Within 5 w $k$, population crashes were recorded for the sedentary polychaetes Manayunkia aestuanna and Pygospıo elegans, while populations of the errant polychaete Nereis diversicolor and tubificid oligochaetes remained stable under the algal mats. Initial short-term recovery after the algae were removed was rapid and domınated by Hydrobia spp. The strong negative effects on key species such as $M$. balthica may have severe effects on entire food-web dynamics in Baltic coastal ecosystems.
\end{abstract}

KEY WORDS: Macrofauna D Drifting macroalgae Disturbance - Baltıc Sea Macoma balthica Hydrobia spp.

\section{INTRODUCTION}

Eutrophication has been recognized as a major threat to coastal marine ecosystems (Rosenberg 1985, Nixon 1990, Gray 1992, Pearl 1995, Bonsdorff et al. 1996), and in sheltered coastal areas the increased growth of benthic macroalgae has often been attributed to the concurrent elevations in nutritional load (Rosenberg 1985, Hull 1987, Raffaelli et al. 1991, Gray 1992, Isaksson \& Pihl 1992, Kolbe et al. 1995). The occurrence of attached algae on tidal flats and other shallow coastal areas has received considerable attention (Perkins \& Abbott 1972, Nicholls et al. 1981. Reise 1983, Hull 1987, Isaksson \& Pihl 1992, ThyboChristesen et al. 1993, Everett 1994, Peterson et al. 1994, Kolbe et al. 1995).

-E-mail: anorkko@abo.fi
A phenomenon ecologically somewhat different to these attached algal mats are the drifting forms of algae which occur in the sublittoral after fragmentation, detachment and transportation from the littoral. These accumulations have not received much attention, as they are not easily observed. Depending on the topographical features of the bottom and local hydrodynamical conditions, algal mats are formed on previously uncovered soft bottoms, and may remain stationary for days to weeks. These mats have a potentially important, underestimated, effect on sublittoral benthic communities (especially along rocky coasts), as described for Ireland (Thrush 1986), the Californian coast (Vetter 1994, 1995) and the Baltic Sea ('Olafsson 1988, Bonsdorff 1992, Norkko \& Bonsdorff 1996a, b). In the northern Baltic Sea drifting algal mats, i.e. conglomerates of several species of threadlike annual brown, green and red algae, have become an increasing problem due to escalating eutrophication (Bons- 
dorff 1992, Bonsdorff et al. 1995, 1996, Norkko \& Bonsdorff $1996 \mathrm{a}, \mathrm{b})$. The macroalgal mats induce structural changes to the habitat. Beneficial influences to the community dominate when the algae occur at low densities, in small patches and for restricted periods of time, increasing habitat complexity and causing intermediate disturbance (sensu Connell 1978). Negative influences to the community dominate when the algae occur at high densities and as larger mats over longer periods of time. Algal respiration and bacterial activity induce oxygen deficiency and anoxia in the interstitial (Reise 1983, Hull 1987) as well as at the algal-sediment interface (Sundbäck et al. 1990, Lavery \& McComb 1991. Norkko \& Bonsdorff 1996a, b). Drifting algal mats affect the benthic community recruitment by filtering of settling pelagic larvae ('Olafsson 1988, Bonsdorff 1992, Bonsdorff et al. 1995), by affecting predator-prey relationships (Norkko \& Bonsdorff 1996a), and by scvercly depleting the infaunal community (Bonsdorff 1992. Norkko \& Bonsdorff 1996b). The shallow, sandy bottoms of the northern Baltic Sea are characterized by low species and functional diversity (Elmgren 1984, Blomqvist \& Bonsdorff 1986). Many species in the food-web have a broader role in community structure and function in comparison to fully marine systems. Losses of key species, such as the bivalve Macoma balthica, might induce fundamental changes to community function and food-web dynamics by altering energy flow in the community.

This study is the first to examine the responses at the population level in order to be able to evaluate speciesspecific responses to the drifting algae and their consequences for community function. We test the temporal responses of benthic populations to the exposure of algal mats in a controlled field experiment on a shallow $(7.5 \mathrm{~m})$ sandy bottom in the northern Baltic Sea, and the pattern of short-term ( $5 \mathrm{~d}$ ) recolonization, after terminated algal stress, in relation to exposure.

\section{MATERIALS AND METHODS}

Study site. The field experiment was conducted in the outermost Aland archipelago in the non-tidal northern Baltic Sea $\left(60^{\circ} 17^{\prime} \mathrm{N}, 19^{\circ} 49^{\prime} \mathrm{E}\right)$ The locality, covering an area of approximately 6 ha, is a semiexposed, 5 to $10 \mathrm{~m}$ deep sound between 2 rocky islets. The sediment consists of medium to fine sand (median grain sizes 0.125 to $0.250 \mathrm{~mm}$; loss on ignition $\approx 0.45 \%$ ). Between May and August temperature varies from 6 to $17^{\circ} \mathrm{C}$ and salinity from 5.9 to $6.2 \%$. Dominating macrofauna are the bivalve Macoma balthica (L.), gastropods Hydrobia spp., polychaetes Pygospio elegans Claparéde, Manayunkia aestuarina (Bourne), Nereis diversicolor O. F. Müller, and oligochaetes. The littoral vege- tation is dominated by Cladophora glomerata (L.) Kuetz., Enteromorphaspp., Pilayella littoralis (L.) Kjellmann and Fucus vesiculosus L. Since the beginning of the 1990s the frequency of occurrence of drifting algal mats has increased (Bonsdorff et al. 1995). During a $6 \mathrm{wk}$ period (July through mid-August) in 1993 a natural drift algal mat covered 2 ha of the bottom. The biomass was estimated at $440.4 \pm 15.8 \mathrm{~g}$ dry wt m $\mathrm{m}^{-2}$.

Experimental set-up and sampling. The accumulations of drifting macroalgal mats and their impact on the zoobenthic populations were studied at a depth of $7.5 \mathrm{~m}$ during $34 \mathrm{~d}$ (from August 11 to September 1.4, 1993). The locality chosen represented a homogenous area which had not been subjected to long-term exposure by drifting algal mats, although some short-term exposure could not be ruled out due to the unpredictable movements of the algal mat. The drift algal mat was comprised of a conglomerate of several species of mainly thread-like algae (e.g. Pilayella littoralis, Ectocarpus siliculosus, Stictyosiphon tortilis, Dictyosiphon foeniculaceus). A detailed account of species composition and relative biomasses of the drift algal species may be found in Norkko \& Bonsdorff (1996b)

Algae were collected with an Ockelmann sledge and were carefully rinsed with seawater in the laboratory to remove macrofauna. An amount of $\approx 510 \mathrm{~g}$ wet wt ( $2050 \mathrm{~g}$ wet wt $\mathrm{m}^{-2}=440 \mathrm{~g}$ dry $\mathrm{wt} \mathrm{m}^{-2}$ ) was sewn into 30 cotton net-bags measuring $50 \times 50 \mathrm{~cm}$ (mesh size: $1.5 \mathrm{~cm}$ ). The net-bags were placed on the bottom and anchored with galvanized wire in 2 rows, $50 \mathrm{~cm}$ apart, covering an area of $22.5 \mathrm{~m}^{-2}$. The design was chosen in order to facilitate sampling by SCUBA diving. The netbags were loose enough for the algae to form an algal mat which behaved naturally. During the experiment the benthic macrofauna were sampled under the algae by removing the net-bags over time (on 5 occasions) and comparing the response with ambient control situations (6 occasions, Fig. 1). Before the removal of algae water samples were taken with a syringe underneath the algae for measurements of temperature and oxygen concentration (Winkler titration). On each occasion, 6 replicate net-bags with algae were randomly removed and macrofauna were sampled in the center of the underlying sediment surface. Similarly, 6 replicate control samples were semi-randomly taken from the ambient area (within a $5 \mathrm{~m}$ radius of the algal plots), using a benthic core-sampler $(4.7 \mathrm{~cm}$ diameter, $10 \mathrm{~cm}$ into the sediment). After the removal of algae and the benthic samples, the plots were marked with thin painted iron rods and revisited after $5 \mathrm{~d}$ to take samples for initial faunal recovery. The recovery samples were taken from a fixed position well away from the iron rods in order to avoid possible effects of rust and altered hydrodynamical conditions. All macrofauna samples were fixed in $4 \%$ buffered formalin, sieved 


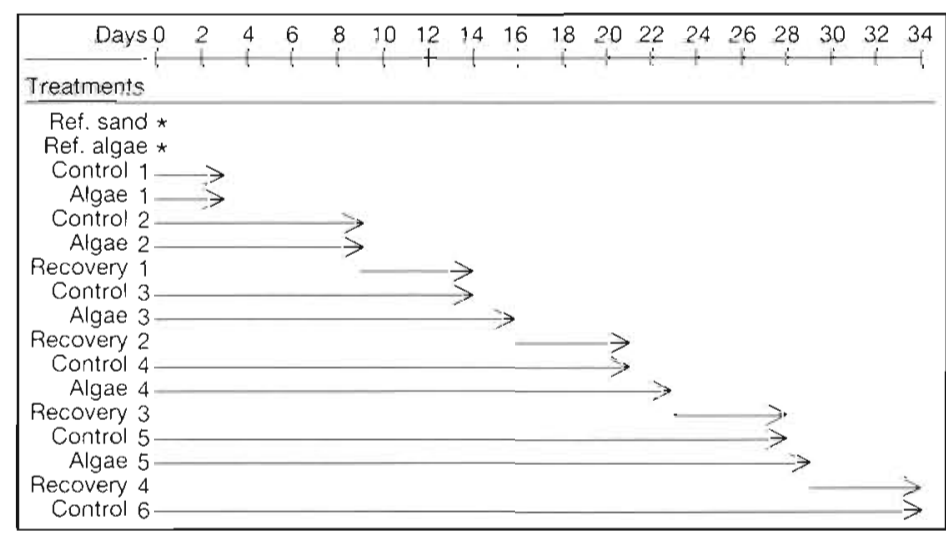

Fig. 1. Experimental design of the field experiment. The graph illustrates the treatments, their durations, and the sampling sequences. "Reference samples $(n=5)$ from bare sand and under natural drifting algal mats at Day 0

through a $0.5 \mathrm{~mm}$ mesh sieve and sorted under a preparation microscope (15x magnification). The animals were identified to species where possible. The experiment consisted of 15 treatments (Fig. 1): 6 control treatments ( $\mathrm{C} 1$ to $\mathrm{C} 6$ ), 5 algae treatments ( $\mathrm{A} 1$ to $A 5)$, and 4 recovery treatments (Rec1. to Rec4). In addition to these treatments, reference macrofauna samples were taken under naturally occurring drifting algal mats (Ref. algae) and from a nearby uncovered bottom area (Ref. sand) on Day 0 (start of the experiment).

Data analysis. Even after transformation, analysis of the macrofaunal data revealed non-normality of distribution (Shapiro-Wilk $W$-test) and heterogeneity of variances (Bartlett's test). The statistical analysis was therefore performed using the non-parametric KruskalWallis H-test (Sokal \& Rohlf 1981). In order to test for the differences between treatments, pairwise comparisons of the mean ranks were made using the formula described in Sachs (1982) which corrects for unequal sample size. When considering recovery after algal stress, the pattern of recovery is directly linked to the situation after the termination of algal stress, and therefore the non-parametric Wilcoxon signed-rank test for dependent samples was performed. All data are presented as mean values \pm standard error per $\mathrm{m}^{2}$

\section{RESULTS}

\section{Hydrographical conditions}

During the experiment average temperature in the bottom water declined from ca 16 to $11^{\circ} \mathrm{C}$, and the chlorophyll a content from $12 \mu \mathrm{g} \mathrm{l}^{-1}$ at the start to $1.6 \mathrm{\mu g} \mathrm{l}^{-1}$ towards the end of the experiment, illustrat- ing the onset of fall and gradual reduction of light intensity and primary production. At the end of the experiment slightly higher temperatures were recorded under the algal plots $\left(13^{\circ} \mathrm{C}\right)$ compared to the free bottom water $\left(11.5^{\circ} \mathrm{C}\right)$. Oxygen content decreased to moderately hypoxic conditions $\left(\sim 2 \mathrm{mg} \mathrm{l}^{-1}\right)$ and hydrogen sulphide was noted under the algal plots already after $9 \mathrm{~d}$ of exposure (Norkko \& Bonsdorff 1996b). The free bottom water was normoxic $\left(\sim 10 \mathrm{mg} \mathrm{l}^{-1}\right)$ throughout the experiment.

\section{Observations from the study site}

The natural occurrences of drifting algal mats exhibit high faunal diversity compared to the adjacent bare sand sediment community; we have recorded 23 invertebrate species/taxa and 3 fish species associated with the algae. The most dominant faunal components are molluscs Hydrobia spp., Mytilus edulis L. and Theodoxus fluviatilis (L.). annelids (tubificid oligochaetes and the polychaete Nereis diversicolor O. F. Müller), the nemertean Prostoma obscurum Schultze, turbellerians and crustaceans (the isopod Idothea balthica Pallas and gammarid amphipods). These species rapidly colonized the experimental algae.

After 9 d (A2, Fig. 1) the sediment surface under the algal plots was completely black, adult Macoma balthica were noted on the sediment surface and some clams had migrated into the algal mass. The same phenomena were observed under natural accumulations of algae. After $16 \mathrm{~d}$ (A3) the algae in the net-bags showed clear signs of deterioration with a gradual formation of mats of sulphur bacteria (Beggiatoa spp.). Towards the end of the experiment ( $A 5 ; 29 \mathrm{~d}$ ) all algal net-bags were completely covered with bacteria. When removing algae during the experiment, epibenthic predators such as gobiids and brown shrimps Crangon crangon (L.) were observed to accumulate in the vicinity of the exposed plots, possibly exploiting stressed infauna at the sediment surface. At the end of the experiment, adult $N$. diversicolor were observed (individuals and burrows) under the algal treatments $A 4$ and A5.

\section{Changes at community level}

The zoobenthic community consisted of 16 infaunal and epibenthic invertebrate species (Table 1). The 7 dominant species/taxa (Macoma balthica, Hydrobia spp., Pygospio elegans, Manayunkia aestuarina, Ne- 


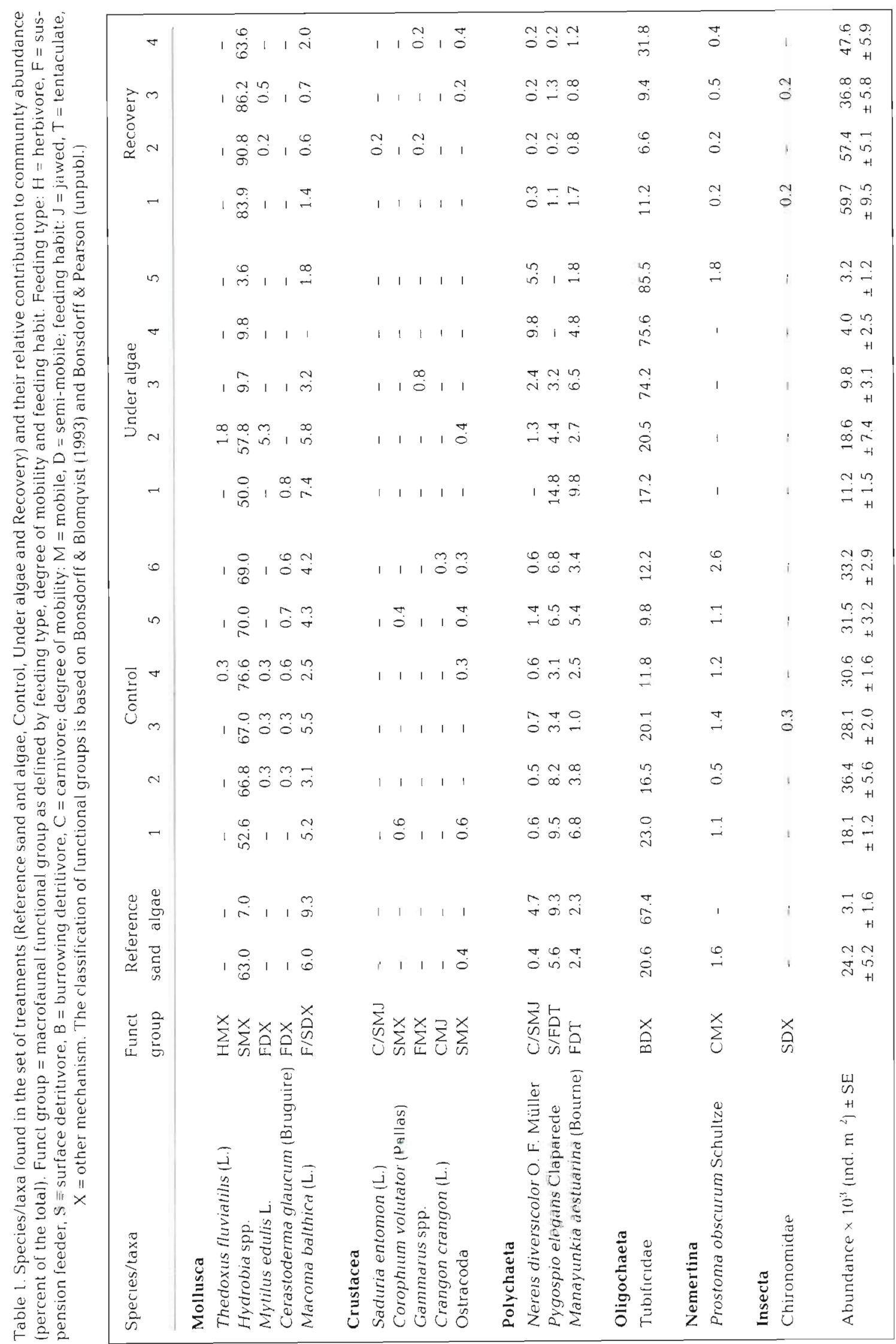


reis diversicolor, Prostoma obscurum and oligochaetes) comprised between 96.7 and $98.8 \%$ of the total abundance and had a $100 \%$ frequency of occurrence in the control treatments ( $\mathrm{C} 1$ to $\mathrm{C} 6$ ). The other species with low abundances, especially the crustaceans, had a stochastic occurrence in the community. Under the experimental algae an initial increase in species numbers, abundance and biomass was followed by a significant decline after $16 \mathrm{~d}$, whereas abundance was already reduced after $9 \mathrm{~d}$ of algal stress (Norkko \& Bonsdorff 1996b; Table 1). After an initial overshoot, community biomass under the algae was reduced towards the end of the experiment (between 23 and $29 \mathrm{~d}$ of algal stress, e.g. A4 and A5); see Norkko \& Bonsdorff (1996b) for other zoobenthic community attributes. Towards the end of the experiment, the pattern under the experimental algae was highly similar to the situation recorded under natural occurrences of drift algal mats (Day 0). This community had been exposed to algae for a period of approximately 4 wk.
The response in biomass was different due to the inherently large variability in size of the Macoma balthica individuals. A significant difference was recorded between Ref. sand and Ref. algae. After only 3 d of algal cover significantly higher biomass values were recorded under algal cover than in the control. This was even more pronounced after $9 \mathrm{~d}$ with $361 \pm 154 \mathrm{~g}$ wet wt $\mathrm{m}^{-2}$ under algae and $99 \pm 60 \mathrm{~g}$ wet $\mathrm{wt} \mathrm{m}^{-2}$ in the control. This may be explained by large adults, initially too deep in the sediment for accurate sampling, emerging closer to the sediment surface. After this, biomass rapidly declined and in the last 2 algal treatments biomass was 0 and $25 \pm 25 \mathrm{~g}$ wet $\mathrm{wt} \mathrm{m}^{-2}$. Due to 1 large individual (12 mm) in A5 no significant differences were recorded between $\mathrm{C} 5$ and A5 (Figs. 2 \& 3). No significant differences were recorded between A4 and A5 and Ref. algae. In the field $M$. balthica were observed to successively emerge to the sediment surface under the algal plots, with a climax after $9 \mathrm{~d}$ of algal cover. An examination of $M$. balthica size distribution showed the control populations to have smaller mean size than those under algal

\section{Responses to algal cover-dominating species}

Baltic clam Macoma balthica. The importance of $M$. balthica in the benthic community studied is illustrated by the fact that it was responsible for $98.6 \%$ of the variation in total biomass. $M$. balthica was relatively abundant in all the control treatments (C1 to $\mathrm{C} 6$ ), ranging between 750 and 1550 ind. $\mathrm{m}^{-2}$ and constituting between 2.5 and $5.5 \%$ of the total abundance (Table 1). Over time (C1 to C6) a significant increase ( $\mathrm{p}<$ 0.001 ) in abundance took place (Fig. 2). After $9 \mathrm{~d}$ of algal cover (A2; Fig. 1) a significant $(p<0.001)$ decline from 1250 to 380 ind. $\mathrm{m}^{-2}$ was registered. After 23 and $29 \mathrm{~d}$ the population exhibited a complete crash with 0 and 96 ind. $\mathrm{m}^{-2}$, respectively, remaining under algal cover (Fig. 2). This was also illustrated by the loss in the $M$. balthica at the community level, with a gradual. decline from $7.4 \%$ (A 1 ) to $0 \%(\mathrm{~A} 4)$ and $1.8 \%$ (A5) of the total abundance under algal cover (Table 1). No significant differences were recorded when comparing abundances under natural occurrences of drift algae (Ref. algae) and the last 2 treatments of experimental algal cover, A4 and A5.

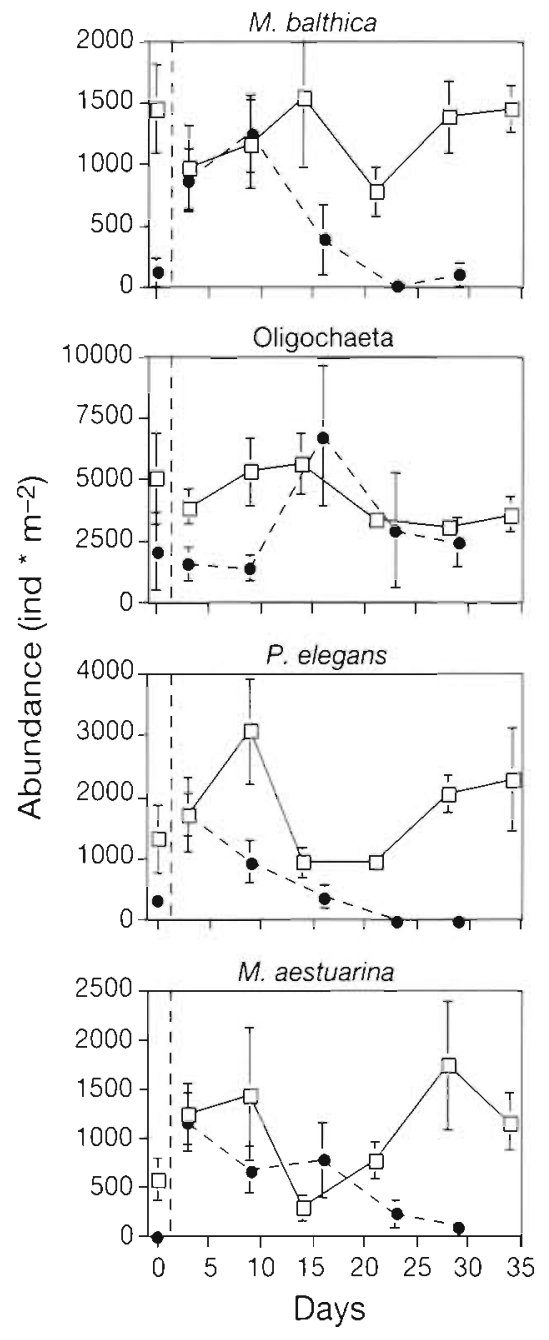

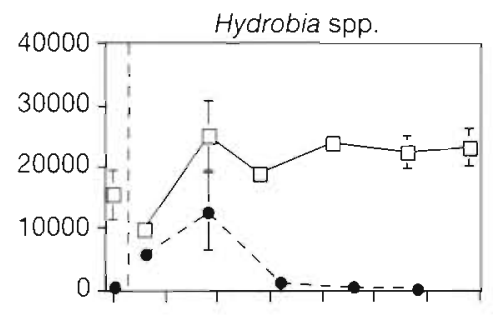
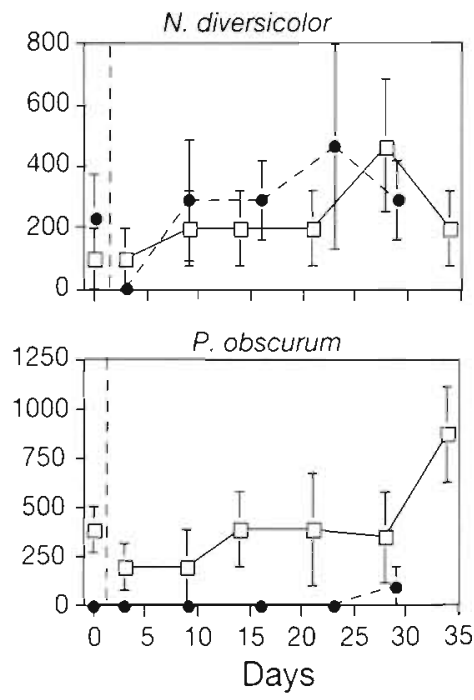

$\begin{array}{ll}\square-\text { control } & \square \text { Ref. sand } \\ ---- \text { under algae } & \text { Ref. algae }\end{array}$

Fig. 2. Responses to drift algal cover (under algae) in abundance over time of the dominant species compared to control treatments and reference samples 


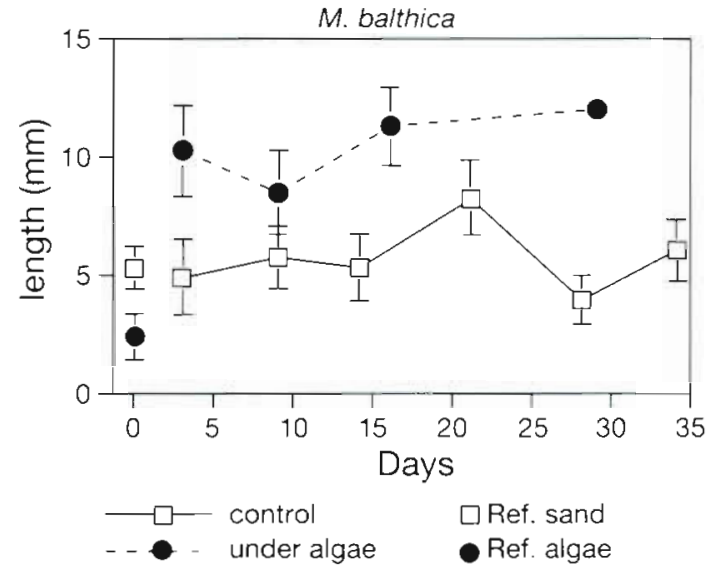

Fig. 3. Macoma balthica. Comparison of average length of the population under algal cover and in control. The larger clams under algae possibly illustrate the size-dependent mortality of juveniles exposed to algal cover

cover (Fig. 3). The total average length of all recorded $M$. balthica in the control treatments was $5.5 \pm 0.6 \mathrm{~mm}$ ( 71 examined individuals), whereas total average length in the algal treatments was $9.6 \pm 1.1 \mathrm{~mm}$ (26 examined individuals). This was not the case in the reference treatments at Day 0 , where average length in Ref. sand was $5.3 \pm 0.9 \mathrm{~mm}$ but only $2.4 \pm 1.0 \mathrm{~mm}$ in Ref. algae (Fig. 3).

Mudsnails Hydrobia spp. The mudsnail species recorded [ $H$. ventrosa (Montagu) and $H$. ulvae (Pennant)] were not separated to species in this study as this should preferably be done with live specimens (Hylleberg 1976). Mudsnails dominated in abundance; $91.2 \%$ of the total variation in abundance was explained by Hydrobia spp. During the experiment (C1 to C6) a significant increase $(p<0.001)$ in abundance of Hydrobia spp. occurred, densities ranging between 10000 and 25000 ind. $\mathrm{m}^{-2}$ (Fig. 2). Hydrobia spp. also constituted between 52.6 and $76.6 \%$ of the total abundance in the control treatments (Table 1). After $9 \mathrm{~d}$ of algal cover (A2) a significant $(p<0.001)$ reduction was recorded compared to the control (C2; Fig. 2). After A2 a sharp decline in abundance followed, from $\approx 12500$ to 1150 ind. $m^{-2}$ (A2 to A3; Fig. 2). Towards the end of the experiment the population crashed with only 460 and 190 ind $\mathrm{m}^{-2}$ remaining under algal cover (A4 and A5; Fig. 2). The relative contribution of Hydrobia spp. to community abundance declined from $57.8 \%$ in A2 to 0 and $1.8 \%$ in A4 and A5, respectively (Table 1). No significant differences were recorded when abundances under natural occurrences of drift algae (Ref. algae), and the last 3 treatments of experimental algal cover (A3 to A5) were compared. A significant difference ( $p<$ $0.001)$ was recorded between Ref. sand and Ref. algae. No significant differences were recorded between A3. $A 4$ and $A 5$ and Ref. algae, illustrating the similarity between experimental algal plots and natural algal cover
Tubificid oligochaetes. The oligochaete species recorded in the study area [Clitellio arenarius (Müller) and Limnodrilus sp.], were not separated in this study. No significant differences were recorded between Ref. sand and Ref. algae (Fig. 2). Despite initially lower densities ( $p<0.001$ ) of oligochaetes under algal cover (A1 and A2), densities increased significantly from A2 to A3. Hereafter oligochaetes seemed indifferent to algal cover with no significant differences recorded between control and algal treatments. The same pattern was seen for biomass. The relative importance of oligochaetes successively increased under algal cover, constituting between 74.2 and $85.5 \%$ of the total abundance in the last 3 treatments compared to between 9.4 and $23.0 \%$ in the control treatments (Table 1 ).

High densities of oligochaete egg-capsules were recorded under algal cover from $\mathrm{A} 2$ onwards. With the exception of $A 5$, the abundance of capsules was significantly higher in $\mathrm{A} 3, \mathrm{~A} 4$, and $\mathrm{A} 6$ than in the control treatments. These capsules ranged in abundance between 700 and $3000 \mathrm{~m}^{-2}$ in algal treatments compared to between 100 and $670 \mathrm{~m}^{-2}$ in the control treatments (Fig. 4).

Errant polychaete Nereis diversicolor. Because of high variability in numbers, no differences in abundance between control and algal treatments of $N$. diversicolor were recorded throughout the experiment. In both control and algal treatments $N$. diversicolor increased (non-significantly) in abundance over experimental time (Fig, 2). The relative contribution of $N$. diversicolor to community abundance increased under algae (from 1.3 to $9.8 \%$ ) compared to the control (Table 1). Several large worms and burrows were observed under the algal plots. No significant differences in biomass were recorded between control and algal treatments, although a significant increase $(\mathrm{p}<$ 0.001 ) in biomass under algae was recorded over time (A1 to A5). This is also reflected as increasing individual weights of the $N$ diversicolor found under algae

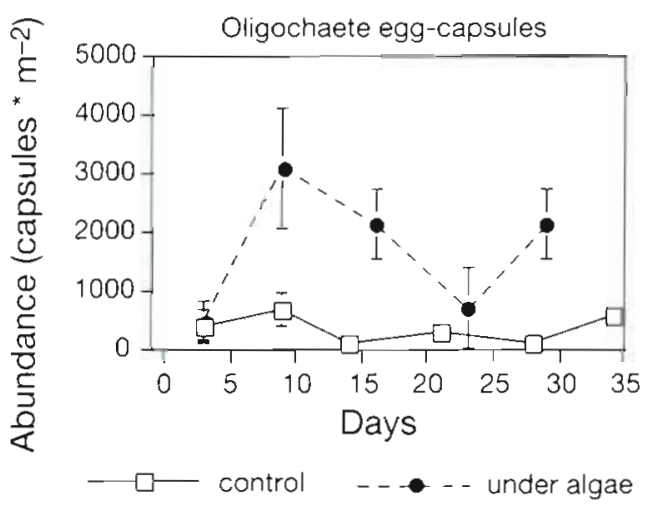

Fig. 4. Olugochaetes. Enhanced occurrence to tubificid eggcapsules under algal cover compared to control 


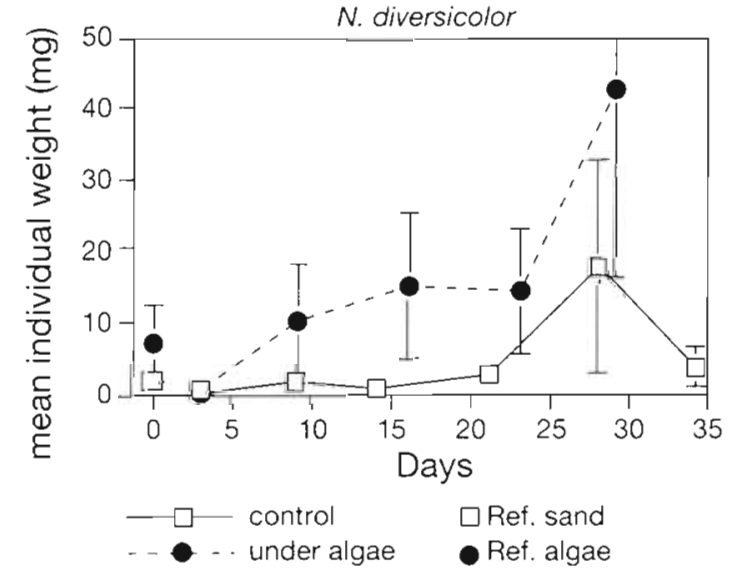

Fig. 5. Nereis diversicolor. Mean individual weight of the polychaete under algal cover compared to control

from A1 to A5 (Fig. 5). Although not significant, average size (mean weight) of the $N$. diversicolor found under algae was larger than in the control.

Sedentary polychaetes Pygospio elegans and Manayunkia aestuarina. The spionid polychaete $P$. elegans exhibited large variability in the control treatments, varying in abundance between 960 and 3074 ind. $\mathrm{m}^{-2}$ (Fig. 2), and contributing between 3.1 and $9.5 \%$ to community abundance (Table 1). A significant decline in abundance occurred under algae (Fig. 2) with no P. elegans present in A4 and A5. This is illustrated by the relative contribution to community abundance as $P$. elegans declined in dominance from 14.8 to $3.2 \%$ (A1 to A3; Table 1). No significant differences were recorded between Ref. algae and A4 and A5. The same decline under algae was apparent in biomass. The control population exhibited a temporary reduction in abundance before increasing again (Fig. 2).

The sabellid polychaete Manayunkia aestuarina had a stochastic occurrence in the control treatments, whereas a steady decline was registered for the $M$. aestuarina exposed to algae (Fig. 2). The relative importance of $M$. aestuarina deteriorated from 9.8 to $1.8 \%$ between $A 1$ and A5 (Table 1). Biomass for $M$. aestuarina was not measured.

Prostoma obscurum. The control population of $P$. obscurum increased significantly $(\mathrm{p}<0.001)$ in abundance over time (Fig. 2); although, occurring in stochastic and low densities. $P$. obscurum were absent under algae until the last treatment A5 (1 individual recorded in 1 of the replicate samples).

\section{Immediate short-term recovery after terminated algal stress}

We have chosen to describe the immediate recovery pattern after terminated algal stress, exemplified with the 2 quantitatively most important species/taxa, Hydrobia spp. and tubificid oligochaetes, and the biomass dominant, Macoma balthica. Samples were taken $5 \mathrm{~d}$ after the algal net-bags had been removed, from treatment A2 onwards (Fig. 1). The recovery of macrofauna was directly linked to the conditions after algal stress; therefore the Wilcoxon signed-rank test was performed as a statistical analysis. $M$. balthica exhibited a random recovery pattern; abundances in Rec1, Rec2 and $\operatorname{Rec} 3$ were not significantly different compared to their respective algal treatment (A2, A3 and A4) and also failed to reach control values (Fig. 6). Only after the last algal treatment (A5) did a significant $(p<0.05)$ recovery (Rec4) occur. Rec4 failed to reach controlvalues $(\mathrm{C} 6)$. The poor short-term recovery rate is reflected in the relative contribution of $M$, balthica to the recovery treatments 10.6 to $2.0 \%$ of community abundance; Table 1). The recovery of Hydrobia spp. was rapid and characterized by overshoots in abundance in the recovery treatments compared to both algal and control treatments (Fig. 6). The short-term recovery process in the community was completely dominated by Hydrobia spp., which is illustrated in Table 1 . Their relative contribution varied between 63.6 and $90.8 \%$ of total community abundance. In the treatments Rec1 and Rec3 abundance values were significantly higher $(p<0.05)$ than background control levels, indicating aggregation on the previously stressed plots. Tubificid oligochaetes had a random recovery pattern which followed the pattern of devel-

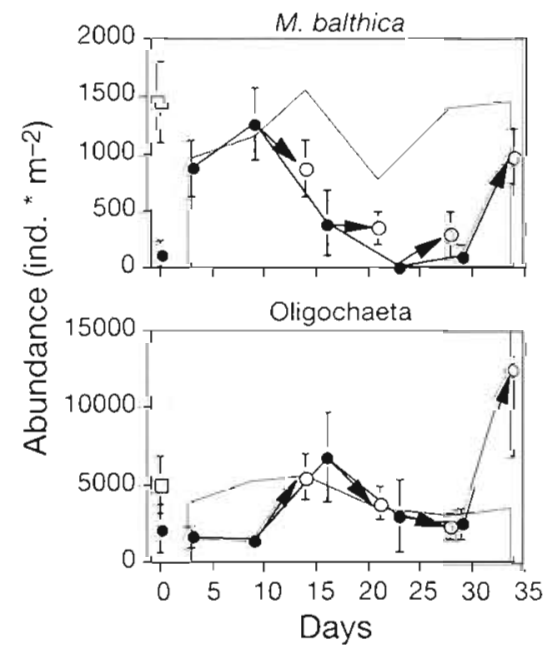

Fig. 6. Immediate recolonization of the community dominants during a $5 \mathrm{~d}$ period after the removal of algal cover. Arrows illustrate recovery from the respective algal treatment. Shaded area indicates background control levels 
opment under algae (Fig 2). This pattern was broken in the last recovery treatment (Rec4) after algal stress from A5, with an overshoot in abundance compared to both control and algal treatments (Fig. 6). The relative contribution of oligochaetes was relatively high in the last recovery treatment, $31.2 \%$ (Table 1 ). The individuals in the last recovery treatment (Rec4) were dominated by small individuals, which is possibly coupled to the availability of egg-capsules under algae (Fig. 4), and to the loss of egg-capsules in Rec4 (290 ind. $\mathrm{m}^{-2}$ ) compared to A5 (2100 ind $\mathrm{m}^{-2}$ ).

\section{DISCUSSION}

\section{Population responses to algal stress}

The effects of the drift algae on the community are dramatic (Norkko \& Bonsdorff 1996b) and similar to those occurring during organic enrichment and hypoxia (Pearson \& Rosenberg 1978, Diaz \& Rosenberg 1995). Hypoxia and anoxia in the bottom water or sediment induce behavioural responses in the benthos. Depending on mobility and tolerance, the species affected experience either migration or death. The general response of infaunal species is to emerge at the sediment surface in their attempt to reach oxygenated water (Jørgensen 1980, Rosenberg et al. 1991). The species-specific responses of the benthos to algal stress are more complex than to mere hypoxia. In addition to the hypoxic/anoxic (and $\mathrm{H}_{2} \mathrm{~S}$ ) conditions in the sediment as well as under the algal mat, the benthic populations also have to cope with the physical structure (Raffaelli et al. 1991) as well as possible toxic exudates from the algae (Aneér 1987). Therefore the speciesspecific responses to hypoxia in general will not be valid when algae interact in the structuring with hypoxia. This is exemplified by Macoma balthica, which exhibits more rapid escape responses when exposed to algal mats compared to exposure of hypoxia only, probably due to both the physical cover of algae disturbing the stretching out of siphons as well as the combined effects of hypoxia and $\mathrm{H}_{2} \mathrm{~S}$ (Norkko \& Bonsdorff 1996a).

The patterns of species responses in our study are similar to those from intertidal flats covered by algae (Nicholls et al. 1981, Soulsby et al. 1982, Hull 1987, Raffaelli et al. 1991, Everett 1994), although fundamental differences are expected as these algae grow attached and may facilitate migrations up into the algae. The contribution of Hydrobia spp. and Macoma balthica to community abundance and biomass is evident. Both species exhibited population crashes after $9 \mathrm{~d}$ of algal cover Mobile epibenthic species such as mudsnails might to some extent benefit from algal cover if they have the capability to move up in the algal mat (Nicholls et al. 1981). Mudsnails were abundant in the algal mat and it seems clear that a part of the population reduction under the algal mat may be explained by emigration. However, large amounts of decomposing mudsnails were found under algal cover Species with restricted mobility, e.g. $M$. balthica, are less successful in escaping unfavourable conditions induced by the algae. The exposed clams successively emerged at the sediment surface, and although $M$ balthica is known to be extremely tolerant to reduced$\mathrm{O}_{2}$ conditions $\left(\mathrm{LT}_{50}\right.$ in anoxia $500 \mathrm{~h}_{i}$ Dries \& Theede 1974), the majority of the clams died at the sediment surface. As we have shown earlier in a set of aquarium experiments (Norkko \& Bonsdorff 1996a) a substantial fraction (13 to $17 \%$ ) of the population will succeed in migrating up into the algae. This was also seen in the field where clams were found in the algae. The response of $M$. balthica is also age-dependent (Fig. 3); juveniles are clearly more sensitive to algal stress (Bonsdorff 1992, Bonsdorff et al. 1995, Norkko \& Bonsdorff 1996a). Species with restricted mobility, the tubiculous polychaetes Pygospio elegans and Manayunkia aestuarina, exhibited steady declines in population abundance when exposed to algal cover over time. The same effects for these species were found by Bonsdorff (1992) and for P. elegans also by Nicholls et al. (1981) and Soulsby et al. (1982). The temporary decline in the control population of $P$. elegans could in part be explained by a generation shift, with a die-off of the senile fraction and recruitment of juveniles to the population. The predatory nemertean Prostoma obscurum was absent under algae with the exception of the last algal treatment, but was found to be abundant in the algae. The reasons for this remain unclear, as no data on the tolerance and behaviour of this species are found

The only species that seem to benefit from alga] cover are the tubificid oligochaetes and Nereis diversicolor. $N$. diversicolor is known to be tolerant to hypoxia and sulfide (Vismann 1990), and so are tubificid oligochaetes (Dubilier et al. 1994), which, in addition, exhibit opportunistic life history traits. Although not increasing in abundance, they were important to community structure by the end of the experiment, constituting $91 \%$ of total community abundance (Table 1). The mean individual size of $N$ diversicolor was larger under the algal mats than those in the control community (Fig 4). This could possibly be due to active immigration to the sediment under algae by large individuals with better mobility than smaller ones. Leppäkoski (1975) and Bonsdorff (1980) found $N$. diversicolor to be a pioneer recolonizing species, with large individuals of the polychaete exhibiting active migrations to previously disturbed bottoms. Many 
nereids are known to be omnivorous, and it is likely that the algae/detritus attracts $N$. diversicolor by providing a favourable food-source. $N$. diversicolor is also known to function as an infaunal predator (Rönn et al. 1988), and it could be possible for the polychaete to feed on stressed infauna or as a scavenger on carrion under the algal mat. Tubificid oligochaetes (i.e. Tubificoides benedii) have been reported as one of the few macrofaunal species/taxa which prevail under algal mats with high concentrations of sulfide (Reise 1985 , Dubilier et al. 1994). We also found significantly higher abundances of tubificid oligochaete egg-capsules under algal cover (Fig. 5), which could be a response to reduced competition and predation, or greater food supply. The oligochaetes are clearly favoured since no reductions in abundance occurred and it is likely that the conditions under algae serve as a refuge

\section{Functional disorder in the zoobenthos?}

As different functional groups respond differentially to algal stress, an important question regarding the consequences and functioning of the system must be raised. An analysis based on the feeding-modes (Bonsdorff \& Blomqvist 1993, Bonsdorff \& Pearson unpubl.) of the benthic species illustrates the fundamental changes induced to the community. When comparing the situation under algae with the control, the changes are apparent (Fig. 7). Surface detritivores (Hydrobia spp., ostracods) and suspension-feeders/surface detritivores (Macoma balthica, Pygospio elegans) decrease in numbers, whereas burrowing detritivores (oligochaetes) together with carnivores/burrowing detritivores ( $N$. diversicolor) increase in relative numbers. The loss of suspension-feeders might induce large-scale alteration of energy flow in the community (Loo \& Rosenberg 1989, Pearson \& Rosenberg 1992). The community dominant, $M$. balthica, is a food source for epibenthic predators (invertebrates and fish) as well as an important feeder on pelagic production (Ankar 1980, 'Olafsson 1986). With large disturbed areas severe effects on food-web complexity might be expected because of the functional changes. As illustrated in Fig 7, changes in the abundance of even a few species may cause dramatic alterations in the dominance of feeding-modes, and may therefore also alter the pattern of energy flow in the community. Every species in the food-web will exhibit a broad niche. Hence, a loss of any species may also induce a loss of a key function.

\section{Recovery after algal stress}

The responses of populations to algal stress in the present experiment corresponded with the situation under naturally occurring algal mats (Fig 2). The modes of recovery (larval settlement or adult migrations) are dependent on the size of the disturbed patch and the mobility of the colonizing species (Günther 1992). The recovery patterns in this study are strongly dependent on the relatively small experimental patches of algae used, and it is natural that the initial colonizers after the perturbation are the dominants of the surrounding community. Since larval settlement may be synchronous in time with the occurrence of algal cover, the majority of the larvae will be filtered and never reach the sediment (Bonsdorff 1992, Bonsdorff et al. 1995), therefore colonization will depend on adult migrations. 'Olafsson et al. (1994) concluded that post-settlement processes are of prime importance in structuring the community. This is apparent in our study as the dominants in abundance, Hydrobia spp., were the most rapid colonizers after terminated algal stress. Hydrobia spp. exceeded natural background values (control) in recovery indicating aggregation to the previously stressed plots. POC/PON ratios of the sediment indicate that the nutritional value of the plots was enhanced compared to control (Norkko \& Bonsdorff 1996b). Levinton \& Bianchi (1981) showed the deposit-feeding Hydrobia totteni to be food-limited and individual growth rates to increase at lower population densities (attributed to exploitation competition). This would explain the rapid exploitation of the mudsnails after algal stress since higher amounts of potential food are available. As concluded by Thistle (1981) hydrobiid snails are highly mobile, continuously moving to fresh patches of food. Examples of a more static life history strategy may be found for capitellids which are

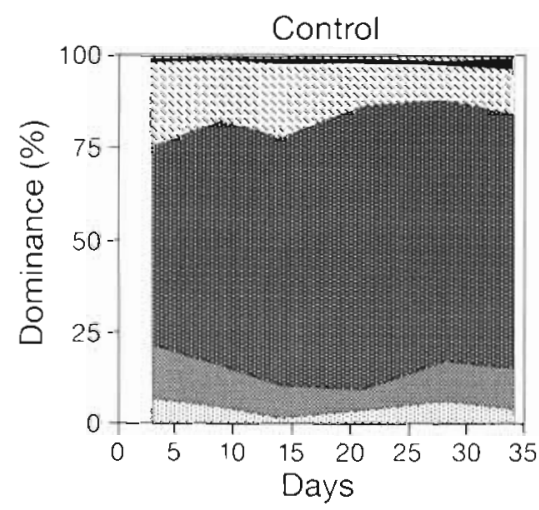

herbivore

suspension feeder/surface detritivore 13 burrowing detritivore

538 carnivore/burrowing detritivore

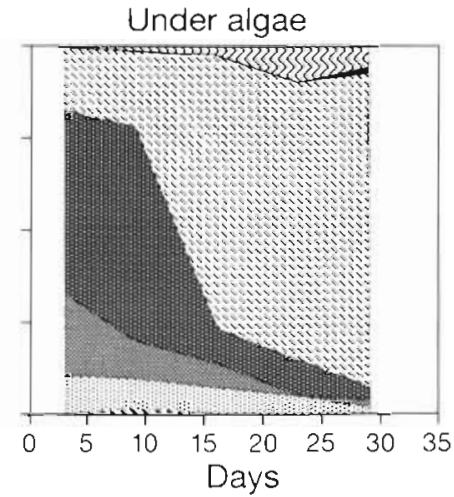

suspension feeder surface detritivore N carnivore
Fig. 7. Changes in the relative dommance of benthe functional groups over time in control and under algae 
adapted to grow and reproduce in a single patch (Thistle 1981). This strategy is probable for the oligochaete species in this study. The high abundance in the last recovery treatment (Rec4) could be explained by oligochaete egg-capsules starting to hatch. The recovery rates for Macoma balthica are slow, and only at the end of the experiment was partial recovery detected. The recovery for $M$. balthica is likely to be governed by random redistribution through resuspension and transport of the sediment (Bonsdorff et al. 1995)

\section{Concluding remarks}

The effects of the drift algal mats on benthic populations depend on the severity of the disturbance as illustrated by increasing exposure time to the experimental algal patches in this study. During low levels of stress, such as small patchos of algae during a restricted period of time, algal cover induced increased community heterogeneity by providing an additional structure to previously bare sand areas, enhancing habitat complexity and the possibility of coexistence between species (Norkko \& Bonsdorff 1996a, b). With increased stress, increased species-specific mortality (depending on tolerance and mobility) is evident, followed by an increased release of resources. Despite local extinctions, the community might still exhibit large-scale stability as undisturbed neighbouring patches serve as donor areas of invading species ('neighbourhood stability'; Gray 1977). A large-scale, or frequent, disturbance may impose large-scale structural. and functional homogeneity. Even if the algae only induce 'intermediate' disturbance, unpredictable population reductions may be caused by the interaction between algal disturbance and biotic factors. These interactions may create stressinduced increases in predation pressure, negatively affecting prey survival (Norkko \& Bonsdorff 1996a). The algae induce hypoxia, exposing a community which has not been conditioned to hypoxic events (Diaz \& Rosenberg 1995); even short-term exposure to algal mats may be regarded as a catastrophic event to the macrofauna, eventually reducing the resources for higher trophic levels. It seems obvious that drift algal mats pose a serious threat to the coastal biodiversity in the Baltic Sea, by altering the 3 major components of biodiversity, i.e. the composition, structure, and subsequent functioning of the community (Lamont 1995).

Acknowledgements. We thank Huso Biological Station for providing excellent working facilities. This study was supported by the Academy of Finland, Swedish Cultural Foundatron, the Foundation of Abo Akademi University, and the Kone-Foundation. We are especially grateful to the students and staff at Husö for help with diving and field work.

\section{LITERATURE CITED}

Anéer G (1987) High natural mortality of Baltic herring (Clupea harengus) eggs caused by algal exudates? Mar Biol 94:163-169

Ankar S (1980) Growth and production of Macoma balthica (L.) in a northern Baltic soft bottom. Ophelia (Suppl) 1:31-48

Blomqvist EM, Bonsdorff E (1986) Spatial and temporal variations of benthic macrofauna in a sandbottom area on Ảland, northern Baltic Sea. Ophelia (Suppl) 4:27-36

Bonsdorff E (1980) Macrozoobenthic recolonization of a dredged brackish water bay in SW Finland. Ophelia (Suppl) 1:145-155

Bonsdorff E (1992) Drifting algae and zoobenthos - offects on settling and community structure. Neth J Sed Res 30:57-62

Bonsdorff E, Blomqvist EM (1993) Biotic couplings on shallow water soft bottoms-examples from the northern Baltic Sea. Oceanogr Mar Biol Annu Rev 31:153-176

Bonsdorff E, Blomqvist EM, Mattila J, Norkko A (1996) Longterm changes and coastal eutrophication. Examples from the northern Baltic Sea. Oceanol Acta 20(1):in press

Bonsdorff E, Norkko A, Boström C (1995) Recruitment and population maintenance of the bivalve Macoma balthica (L.) - factors affecting settling success and early survival on shallow sandy bottoms. Proc 28th Europ Mar Biol Symp. Olsen \& Olsen, Fredensborg, p 253-260

Connell JH (1978) Diversity in tropical rain forests and coral reefs. Science 199:1302-1310

Diaz RJ, Rosenberg R (1995) Marine benthic hypoxia: a review of its ecological effects and the behavioural responses of benthic macrofauna. Oceanogr Mar Biol Annu Rev 33:245-303

Dries RR, Theede H (1974) Sauerstoffmangelresistenz mariner Bodeninvertebraten aus der westlichen Ostsee. Mar Biol $25: 327-333$

Dubilier N, Giere O, Grieshaber MK (1994) Concomitant effects of sulfide and hypoxia on the aerobic metabolism of the marine oligochaete Tubificoides benedii. J Exp Zool $269: 287-297$

Elmgren R (1984) Trophic dynamics in the enclosed, brackish Baltic Sea. Rapp PV Réun Cons Int Explor Mer 183:152-169

Everett RA (1994) Macroalgae in marine soft-sediment communities: effects on benthic faunal assemblages. J Exp Mar Biol Ecol 175:253-274

Gray JS (1977) The stability of benthic ecosystems. Helgol Meeresunters 30:424-444

Gray JS (1992) Eutrophication in the sea. In: Columbo GC, Ferrari I, Ceccherelli VU, Rossi R (eds) Marne eutrophication and population dynamics. Proc 25th Eur Mar Biol Symp. Olsen \& Olsen, Fredensborg, p 3-15

Günther CP (1992) Dispersal of intertidal invertebrates: a strategy to react to disturbances of different scales. Neth J Sea Res 30:45-56

Hull SC (1987) Macroalgal mats and species abundance: a fjeld experiment. Estuar Coast Shelf Sc1 25:519-532

Hylleberg J (1976) Mud snails on Ảland. Medd Huso Biologuska Stn 18:11-22

Isaksson I, Pihl L (1992) Structural changes in benthic macrovegetation and associated epibenthic faunal communities. Neth J Sea Res 30:131-140

Jørgensen BB (1980) Seasonal oxygen depletion in the bottom waters of a Danish fjord and its effect on the benthic community. Oikos 34:68-78

Kolbe K, Kaminski E, Michaelis H, Obert B, Rahmel J (1995) Macroalgal mass development in the Wadden Sea: first experiences with a monitoring system. Helgol Meeresunters $49: 1-4$ 
Lamont BB (1995) Testing the effect of ecosystem composition/structure on its functioning. Oikos 74:283-295

Lavery PS, McComb AJ (1991) Macroalgal-sediment nutrient interactions and their importance to macroalgal nutrition in a eutrophic estuary. Estuar Coastal Shelf Sci 32 $281-295$

Leppäkoski E (1975) Assessment of degree of pollutıon on the basis of macrozoobenthos in marine and brackish-water environments. Acta Acad Abo Math Phys Mat Naturvetensk Tek (Ser B) 35:1-90

Levinton JS, Bianchi TS (1981) Nutrition and food limitation of deposit feeders. I. The role of microbes in the growth of mud snails (Hydrobiidae). J Mar Res 39:531 356

Loo LO, Rosenberg R (1989) Bivalve suspension feeding dynamics and benthic-pelagic coupling in an eutrophcated marine bay. J Exp Mar Biol Ecol 130:253-273

Nacholls DJ, Tubbs CR, Hayes FN (1981) The effect of green algal mats on intertidal macrobenthic communities and their predators. Kieler Meeresforsch (Sonderh) 5:511-520

Nixon SW (1990) Marine eutrophication: a growing international problem. Ambio 19:101

Norkko A, Bonsdorff E (1996a) Altered benthic prey-availability due to episodic oxygen deficiency caused by drifting algal mats. PSZN 1: Mar Ecol 17(1):in press

Norkko A, Bonsdorff E (1996b) Rapid zoobenthic community responses to accumulations of drifting algae. Mar Ecol Prog Ser 131:143-157

Olafsson EB (1986) Density dependence in suspension-feeding populations of the bivalve Macoma balthica. A field experiment. J Anim Ecol 55:517-526

'Olafsson EB (1988) Inhibition of larval settlement to a soft bottom benthic community by drifting algal mats: an experimental test. Mar Biol 97:571-574

'Olafsson EB, Peterson CH, Ambrose WG (1994) Does recruitment limitation structure populations and communities of macro-invertebrates in marine soft sediments: the relative significance of pre- and post-settlement processess. Oceanogr Mar Biol Annu Rev 32:65-109

Pearl HW (1995) Coastal eutrophication in relation to atmospheric nitrogen deposition: current perspectives. Ophelia 4.1:237-259

Pearson TH, Rosenberg R (1978) Macrobenthic succession in relation to organic enrichment and pollution of the marine environment. Oceanogr Mar Biol Annu Rev 16:229-311

Pearson TH, Rosenberg R (1992) Energy flow through the SE Kattegatt: a comparative examination of the eutrophication of a coastal marine ecosystem. Neth J Sea Res 28 $317-334$

Perkins EJ, Abbott OJ (1972) Nutrient enrichment and sand flat fauna. Mar Pollut Bull 3:70-72

This article was presented by J. Gray (Senior Editorial Advisor), Oslo, Norway
Peterson CH, Irland EA, Black R (1994) The crash in suspension-feeding bivalve populations (Katelysia spp.) in Princess Royal Harbour: an unexpected consequence of eutrophication. J Exp Mar Biol Ecol 176:39-52

Raffaelli D, Limia J, Hull S, Pont S (1991) Interactions between the amphipod Corophum volutator and macroalgal mats on estuarine mudflats. J Mar Biol Ass UK 71. $899-908$

Relse K (1983) Sewage, green algal mats anchored by lugworms, and the effects on Turbelleria and small Polychaeta. Helgol Meeresunters 36:151-162

Reise K (1985) Tidal flat ecology. An experimental approach to species interactions. Springer Verlag, Berlin

Rönn C, Bonsdorff E. Nelson WG (1988) Predation as a mechanism of interference within infauna in shallow brackish water soft bottoms; experıments with an infauna predator, Nereis diversicolor O. F. Muller. J Exp Mar Biol Ecol 116: $143-157$

Rosenberg R (1985) Eutrophication - the future marine coastal nuisance? Mar Pollut Bull 16:227-231

Rosenberg R, Hellman B, Johansson B (1991) Hypoxıc tolerance of marine benthic fauna. Mar Ecol Prog Ser 79 $127-131$

Sachs L (1982) Applied statistics, a handbook of techniques. Springer Verlag. New York

Sokal RR, Rohlf FJ (1981) Biometry. W H Freeman \& Co, San Fransisco

Soulsby PG, Lowthion D, Houston M (1982) Effects of macroalgal mats on the ecology of intertidal mudflats. Mar Pollut Bull 13:162-166

Sundbäck K, Jönsson B. Nilsson P, Lindström l (1990) Impact of accumulating dritting macroalgae on a shallow-water sediment system: an experimental study. Mar Ecol Prog Ser 58:261-274

Thistle D (1981) Natural physical disturbances and communities of marine soft bottoms. Mar Ecol Prog Ser 6:223-228

Thrush SF (1986) The sublittoral macrobenthic community structure of an Irish sea-lough: effect of decomposing accumulations of seaweed. J Exp Mar Biol Ecol 96:199-212

Thybo-Cristesen M, Rasmussen MB, Blackburn TH (1993) Nutrient fluxes and growth of Cladophora sencea in a shallow Danish Bay. Mar Ecol Prog Ser 100:273-281

vetter ER (1994) Hotspots of benthic production. Nature $372: 47$

Vetter ER (1995) Detritus-based patches of high secondary production in the nearshore benthos. Mar Ecol Prog Ser 120:251-262

Vismann B (1990) Sulfide detoxification and tolerance in Nereis (Hediste) diversicolor and Nereis (Neanthes) virens (Annelida: Polychaeta). Mar Ecol Prog Ser 59:229-238

Manuscript first received: February 23, 1996

Revised version accepted: June 5, 1996 